УДК 551.4; DOI: 10.30970/gpc.2021.1.3463

СУЧАСНА УКРАЇНСЬКА ГЕОМОРФОЛОГІЯ: ЗДОБУТКИ, ПРОБЛЕМИ, ПЕРСПЕКТИВИ (ДО 70-РІЧЧЯ КАФЕДРИ ГЕОМОРФОЛОГІЇ І ПАЛЕОГЕОГРАФІЇ ЛНУ ІМЕНІ ІВАНА ФРАНКА) Іван Ковальчук ${ }^{1}$, Лідія Дубіс ${ }^{2}$

${ }^{1}$ Національний університет біоресурсів і природокористування України, kovalchukip@ nubip.edu.ua; https://orcid.org/0000-0002-2164-1259;

${ }^{2}$ Львівський наиіональний університет імені Івана Франка, lidia.dubis@1nu.edu.ua; http://orcid.org/0000-0001-5231-3920

Анотація. Представники спеціальності, науки чи наукового напряму періодично обговорюють їхній стан, проблеми, перспективи розвитку. Великою мірою це стосується і такої геолого-географічної науки, як геоморфологія. Підставою для аналізу її статусу, проблемних питань, стану і перспектив розвитку став 70-річний ювілей кафедри геоморфології і палеогеографії Львівського національного університету імені Івана Франка, який відзначала геоморфологічна громадськість України і країн-сусідів 2020 року. Йому присвячено Всеукраїнську науково-практичну конференцію "Сучасний стан і перспективи розвитку геоморфології та палеогеографії в Україні". На конференції прозвучали доповіді Лідії Дубіс, Ярослава Кравчука, Івана Ковальчука, Андрія Богуцького, Володимира Стецюка, Романа Спиці, Жанни Матвїшиної, Наталії Герасименко, Галини Байрак, Петра Волошина, Олександра Мкртчяна, Андрія Яцишина та інших дослідників, які відображали сучасні напрями геоморфологічних та палеогеографічних досліджень учених України, піднімали проблемні питання. Враховуючи цю обставину, спробуємо дати відповіді на запитання, які виникають і в самих геоморфологів, й у фахівців суміжних галузей географічної та геологічної науки, зокрема: чи достатньо уваги приділяють аналізу сучасного стану науки про рельєф і процеси рельєфоутворення в Україні; якими здобутками володіє геоморфологія 20-х років XXI століття; як співвідноситься українська геоморфологія з зарубіжною за доробком, методами дослідження, отриманими результатами, суспільним визнанням; які проблеми має розв'язувати геоморфологічна і палеогеографічна наука, щоб залишатися сучасною і суспільно важливою; які перепони вона має долати; які перспективи іiі очікують?

Висвітлені результати досліджень базуються на аналізі публікацій, присвячених сучасному стану геоморфологічної науки, доповідей на конференціях різних рангів, творчого доробку фундаторів української геоморфології, її дійових осіб, які працювали у XIX-XXI століттях чи продовжують працювати нині, узагальненні результатів власних досліджень проблем геоморфологічної науки.

Ключові слова: сучасна українська геоморфологія; проблеми геоморфології; перспективи геоморфологічних досліджень.

\title{
MODERN UKRAINIAN GEOMORPHOLOGY: ACHIEVEMENTS, PROBLEMS, PROSPECTS (ON THE OCCASION OF THE 70TH ANNIVERSARY OF THE DEPARTMENT OF GEOMORPHOLOGY AND PALEOGEOGRAPHY OF IVAN FRANKO NATIONAL UNIVERSITY OF LVIV) Ivan Kovalchuk $^{1}$, Lydia Dubis ${ }^{2}$
}

СКовальчук Іван, Дубіс Лідія, 2021. 


\author{
${ }^{1}$ National University of Life and Environmental Sciences of Ukraine \\ ${ }^{2}$ Ivan Franko National University of Lviv
}

Abstract. Representatives of the specialty, science or scientific field periodically discuss their condition, problems, prospects for development. This applies to a large extent to geomorphology as geological and geographical science. The analysis of its status, problematic issues, state and prospects of development was highlighted during the 70th anniversary of the Department of Geomorphology and Paleogeography of Ivan Franko National University of Lviv, which was celebrated by the geomorphological community of Ukraine and neighboring countries in 2020. The All-Ukrainian scientific-practical conference "Current state and prospects of development of geomorphology and paleogeography in Ukraine" was dedicated to this matter. It featured reports by Lydia Dubis, Jaroslav Kravchuk, Ivan Kovalchuk, Volodymyr Stetsiuk, Andriy Bogutsky, Roman Spitsa, Natalia Gerasimenko, Galyna Bayrak, Petro Voloshin, Oleksandr Mkrtchyan, Andriy Yatsyshyn and other researchers, which reflected modern trends in geomorphological and paleogeographical research. Given this fact, we will try to answer a range of questions that are raised by both the geomorphologists themselves and in specialists in related fields of geographical and geological science. These include, in particular: can we consider the attention, paid to the analysis of the current state of the science of relief and the processes of relief formation in Ukraine sufficient? What are the achievements of geomorphology of the 20s of the XXI century? How does Ukrainian geomorphology relate to foreign geomorphology in research methods, results obtained, and public recognition? What problems does geomorphological and paleogeographic science have to solve in order to remain modern and socially important? What obstacles does it have to overcome? What prospects await her?

The highlighted research results are based on the analysis of publications, reports at conferences of various ranks, creative work of the founders of Ukrainian geomorphology, its protagonists who worked in the XIX - XXI centuries or continue to work today, summarizing the results of own research on geomorphological science.

Key words: modern Ukrainian geomorphology, problems of geomorphology, prospects of geomorphological researches.

\title{
Вступ
}

Час від часу представники тієї чи іншої спеціальності, науки чи наукового напряму обговорюють стан, проблеми, перспективи розвитку науки або спеціальності. Не є винятком у цьому сенсі доволі відома геолого-географічна наука - геоморфологія. Підставою для обговорення іiі статусу, проблемних питань, стану i перспектив розвитку став 70-річний ювілей кафедри геоморфології і палеогеографії Львівського національного університету імені Івана Франка, який відзначала і геоморфологічна громадськість України, i геоморфологи зарубіжних країн-сусідів 2020 року. Враховуючи цю обставину, спробуємо відповісти на спектр запитань, які виникають $\mathrm{i}$ в самих геоморфологів, й у фахівців суміжних галузей географічної та геологічної науки. До них, зокрема, відносимо такі: чи достатньо уваги приділяють аналізу сучасного стану науки про рельєф і процеси рельєфоутворення; якими рисами володіє сучасна наука про рельєф, геоморфологія 20-х років XXI століття; як співвідноситься українська геоморфологія зі своїми зарубіжними сестрами за доробком, методами дослідження, отриманими результатами, суспільним визнанням; які проблеми має розв'язувати ця наука, щоб залишатися сучасною i суспільно важливою; які перепони вона має долати; які перспективи іiі очікують? 
Однозначних відповідей на ці складні запитання, мабуть немає. Якщо ж їх не піднімати і не обговорювати, то й вирішення ні існуючих проблем, ні поточних, ні нових досягти не вдасться...

Окреслене коло питань дає змогу сформулювати мету дослідження - оцінити минуле і стан сучасної української геоморфології, виявити найактуальніші проблеми та окреслити перспективи розвитку цієї науки.

Для досягнення мети намагатимемося вирішити такі завдання: 1) проаналізувати сучасний стан української геоморфології, виявити іiї здобутки і проблеми, які потребують поглиблених досліджень; 2) обговорити перспективи розвитку геоморфологічної науки, визначити комплекс заходів, впровадження яких даватиме змогу можливість досягти поставленої мети.

Аналіз публікацій і методика досліджень. Сучасний стан (кінець XX -20-і роки XXI століття) української геоморфології та іï окремих галузей оцінювали такі українські вчені, як О. М. Адаменко, Ю. С. Бортник, Л. Ф. Дубіс, І. П. Ковальчук, Я. С. Кравчук, О. М. Маринич, В. П. Палієнко, Е. Т. Палієнко, В. В. Стецюк, Г. І. Рудько, І. Г. Черваньов, Ю. Д. Шуйський та ін. Стосовно палеогеографічної складової геоморфології зазначимо, що їй присвячені праці А. Б. Богуцького, П. Ф. Гожика, Н. П. Герасименко, Ж. М. Матвіїшиної, О. О. Комлєва та ін. (Ковальчук, 2004, 2004 а; Ковальчук, Кравчук, 2001).

Доповіді цих учених звучали на VII (1995) i IX (2004) з'їздах УГТ, спеціалізованій конференції "Українська геоморфологія: стан і перспективи" (Львів, 1997), на конференції до 50-річчя кафедри геоморфології ЛНУ імені Івана Франка (2000), IV Щукінських читаннях (Москва, 2000), міжнародній конференції до 120-річчя географії у цьому університеті (2003), Пленумі Геоморфологічної комісії РАН (2008), конференціях в КНУ імені Тараса Шевченка $(2009,2019)$ і конференції, присвяченій 70-річчю кафедри геоморфології і палеогеографії ЛНУ імені Івана Франка (2020) та ін.

Варто згадати і низку публікацій у таких часописах: Фізична географія та геоморфологія (2005, 2009, 2010, 2019), Український географічний журнал, Історія української географії, Проблеми геоморфології і палеогеографії Українських Карпат і прилеглих територій (2007, 2013, 2014,), Вісник Львівського університету, серія географічна (2001, 2013 та ін.) тощо.

У зазначених доповідях і публікаціях увагу акцентовано насамперед на історії української геоморфології, іiї постатях, напрямах досліджень, отриманих результатах. Можна констатувати, що цілеспрямовані геоморфологічні дослідження території України розпочиналися у XIX - на початку XX століття і були складовою геолого-географічного вивчення надр і природи нашої держави. Вони були відповіддю на запити господарської практики та враховували розвиток цих галузей науки в Європі і світі. Серед когорти дослідників геологогеоморфологічної будови західної і північної частин України зазначимо: академіка П. Тутковського (1902 та ін.), який зробив значний внесок у вивчення генезису лесів (обгрунтував еолову теорію їхнього походження) та льодовикових відкладів і створених ними форм рельєфу; академіка С. Рудницького (1905, 1907, 1913), який виконав детальний морфологічний аналіз рельєфу карпатської та подільської частин сточища Дністра, охарактеризував будову та історію розвитку його рельєфу, здійснив районування, висвітлив питання формування поверхонь вирівнювання, зледеніння Сянсько-Дністерського межиріччя, зв'язок рельєфу i 
тектонічної будови, формування рельєфу вулканічного генезису у Закарпатті тощо (Академік Степан Рудницький..., 1994; Кравчук, 2017; Кравчук, Зінько, 2019); Ю. Полянського (1929), який детально дослідив терасовий комплекс, лесовий покрив галицького Поділля, пов'язуючи їх 3 археологічними культурами; Е. Ромера (1909 та ін.) - вивчення зв'язків морфології і морфометрії рельєфу Східних Карпат 3 їньою геологічною структурою, застосування генетико-хронологічного підходу до досліджень рельєфу долини Дністра та зледеніння Карпат; Г. Тейсейра (1938 та ін.), який багато уваги приділяв формуванню вершинних поверхонь Карпат, поверхонь вирівнювання Передкарпаття тощо; А. Ціргофера (1926) - дослідження проблем палеогеоморфології Поділля; В. Лозинського (вчення про перигляціал, вплив тектонічних рухів на розвиток річок Карпат), Б. Свідерського (1938 та ін.) дослідження молодих тектонічних рухів Карпат, зв'язків 3 ними морфології рельєфу, процесів ерозії, зледеніння та денудації поверхні гір, геоморфологічної будови Чорногори; Я. Чижевського (питання формування долини Дністра, аналіз морфології рельєфу Покуття та ін.); у другій половині XX століття в цій частині України з'являється плеяда нових дослідників - К. Геренчук (1960), П. Цись (1961), І. Гофштейн $(1962,1964)$, які розвивали як морфогенетичний напрям геоморфології, так і тектоно-орографічний, який згодом трансформувався у неотектонічний i морфоструктурний; у 70-90-х роках XX століття активно виконують дослідження I. Гофштейн $(1979,1995)$, К. Геренчук, В. Палієнко, С. Круглов, О. Адаменко, Я. Кравчук, Г. Міллер, І. Черваньов, Л. Скварчевська, Б. Лящук, Д. Стадницький, Ю. Срмоленко, А. Богуцький, I. Ковальчук, а наприкінці XX - на початку XXI ст. - Я. Кравчук, I. Ковальчук, Г. Рудько, О. Адаменко, А. Богуцький, Л. Дубіс, Ю. Зінько, Я. Хомин, В. Шушняк, Р. Гнатюк, В. Брусак, Г. Байрак, М. Симоновська, А. Михнович, О. Пилипович, Л. Курганевич, С. Іванов, Ю. Андрейчук, П. Горішний, А. Яцишин, Р. Дмитрук. В цей період увагу акцентують на польових, стаціонарних та експериментальних дослідженнях процесів рельєфоутворення, великомасштабному картографуванні їхнього поширення, оцінюванні впливу на угіддя, комунікації, господарські об'єкти; розвивається регіональна, динамічна, антропогенна, екологічна геоморфологія, палеогеографія плейстоцену, геодинаміка. У дослідженнях задіюють методи Д3З та геоінформаційно-картографічного моделювання, виконують госпдоговірні та дерджбюджетні дослідження інженерногеоморфологічного, природоохоронного та еколого-геоморфологічного i палеогеографічного спрямування (наукові керівники професори Я. Кравчук, I. Ковальчук, Г. Рудько, А. Богуцький, доц. В. Брусак у Львові, професор О. Адаменко в Івано-Франківську), захищають серію кандидатських та докторських дисертацій.

Великий внесок у вивчення геоморфології північної, центральної, східної і південної частин України зробили К. Феофілактов, П. Армашевський, М. Андрусов, В. Ласкарєв, П. Тутковський (1902 та ін.), В. Різниченко, В. Лучицький, Б. Лічков, М. Дмитрієв (1936), В. Крокос (1927), В. Бондарчук, П. Заморій, I. Підоплічко, Г. Молявко, дещо згодом - О. Маринич, I. Соколовський (1973), М. Веклич, I. Рослий, Ю. Кошик, В. Палієнко, С. Проходський, I. Черваньов, П. Гожик, Ж. Матвіїшина, М. Волков, В. Галицький, М. Барщевський, Ю. Грубрін, Н. Герасименко, Е. Палієнко, 
I. Мельничук, В. Стецюк, Ю. Бортник, О. Комлєв, Ю. Спиця, О. Ободовський, Г. Швебс, О. Світличний, Ю. Шуйський, Г. Вихованець, А. Оліферов, В. Дублянський, Б. Вахрушев, В. Боков, В. Корженевський, О. Клюкін, Є. Толстих та ін. Тематика їхніх досліджень була різноманітною: генезис і вік рельєфу, рельєфоутворювальні відклади, способи їхнього утворення, тектонічна i геологічна будова та ії вплив на рельєф, структурний і морфометричний аналіз рельєфу, структурна, кліматична, інженерна геоморфологія, геоморфологія карсту, геоморфологічні процеси на морських узбережжях, сельові i зсувні процеси, стратиграфія і датування відкладів плейстоцену і викопних грунтів, еолові та ерозійні процеси, моделювання і прогнозування їхнього розвитку, руслові процеси, питання екологічної геоморфології та геоекології тощо.

Стосовно методики досліджень стану української геоморфології зазначимо, що основними її методами виступали: 1) пошуки та аналіз публікацій учених (монографій, статей, фондових матеріалів); 2) безпосереднє спілкування 3 відомими вченими-геоморфологами під час з'їдів Українського географічного товариства, конференцій, присвячених проблемам цієї науки та ювілеям кафедр геоморфології, їх керівникам тощо; 3) осмислення та узагальнення різноманітної інформації, яка стосувалася стану геоморфології, палеогеографії, фізичної географії, географії плейстоцену, неотектоніки та проблем і перспектив їхнього розвитку; 4) використання авторського досвіду дослідження стану і розвитку різних галузей геоморфології.

Зокрема, цим питанням присвячені такі наші (і співавторів) праці:

1. І. П. Ковальчук "Українська геоморфологія: історія, напрями, завдання, проблеми" (Київ, 1995);

2. І. Ковальчук "Вектори розвитку української геоморфології" (Львів, 2001);

3. I. П. Ковальчук "Українська екогеоморфологія: стан, завдання, перспективи, проблеми" (Львів , 1997);

4. О.М.Адаменко, И. П. Ковальчук, Я. С. Кравчук, и др. "Украинская геоморфологическая школа: истоки, становление, взгляд в будуще" (Москва, 2000);

5. І. П. Ковальчук, Я. С. Кравчук "Кафедрі геоморфології Львівського національного університету імені Івана Франка - 50" (Львів, 2001);

6. І. Ковальчук "Професор Петро Цись: внесок у розвиток української геоморфології" (Тернопіль, 2004);

7. І. П. Ковальчук "Українська геоморфологія на межі тисячоліть: здобутки, проблеми, перспективи" (Київ , 2005);

8. Я. С. Кравчук "Кафедра геоморфології і палеогеографії Львівського національного університету імені Івана Франка (1950-2004рр.)" (Львів, 2007);

9. И. П. Ковальчук "Проблемы и перспективы геоморфологических исследований территории Украины" (Санкт-Петербург, 2008);

10.І. П. Ковальчук "Українська екологічна геоморфологія: історія, сьогодення, майбутнє" (Київ, 2009);

11. І. Ковальчук «Екологічна геоморфологія в Україні: історія, сьогодення, перспективи» (Львів-Ворохта, 2010 );

12. Я. С. Кравчук "Геоморфологія i палеогеографія у Львівському національному університеті (1961-2011)" (Львів, 2012); 
13. И.П. Ковальчук, О. В. Колтун "Антропогенная геоморфология как наука и учебная дисципліна" (Москва : Белгород, 2012).

Стосовно наукових шкіл української геоморфології зазначимо, що їхній стан висвітлювали як в окремих статтях, так і в спеціалізованих довідкових виданнях, бібліографічних покажчиках, зокрема:

1. "Андрій Богуцький" (укладачі А. Яцишин, Н. Прицюк; Львів, 2008);

2. С. Ю. Бортник, Е. Т. Палієнко, В. В. Стецюк та ін. "Геоморфологія та палеогеографія у Київському університеті" (Київ , 2009);

3. "Жанна Миколаївна Матвіїшина" $\quad$ (укладачі
А. С. Івченко, та ін.; відп. ред. Л. Г. Руденко; Київ, 2018);

4. Іван Ковальчук: біобібліографічний покажчик (укладачі : Г. Домбровська, А. Михнович; наук. ред. проф. А. Мельник; Львів, 2002);

5. С. Бортник, В. Стецюк, О. Комлєв та ін. "Кафедра землезнавства та геоморфології Київського університету: погляд з XXI століття" (Львів, 2020);

6. І. П. Ковальчук "Українські геоморфологічні наукові школи: джерела, здобутки, перспективи" (Київ, 2012);

7. I. Ковальчук "Розвиток географічної науки у Львові за роки незалежності України: структура, наукові школи, здобутки, проблеми" (Львів, 2013);

8. "Кафедра геоморфології і палеогеографії: довідкове видання" (за заг. ред. проф. Я. С. Кравчука; Львів, 2007);

9. Е. Т. Палієнко, Г. І. Рудько, Ю. А. Сілецький та ін. "Наукова школа інженерної та екологічної геоморфології у Київському національному університеті імені Тараса Шевченка : довідкове видання" (Київ, 2010);

10. "Науковий доробок доктора геолого-мінералогічних наук, доктора географічних наук, доктора технічних наук, професора Рудька Георгія Ілліча 1980-2019 рр.: бібліографічний покажчик" (упорядник Ю. В. Бабич; Київ, 2019);

11. І. Г. Черваньов, $\quad$ С. В. Костріков, $\quad$ Б. Н. Воробйов "Флювіальні геоморфосистеми" (Харків, 2006);

12. І. Г. Черваньов "Дослідження рельєфу представниками харківської геоморфологічної школи" (Київ, 2012);

13. Я. Кравчук, I. Ковальчук, Л. Дубіс "Кафедра геоморфології і палеогеографії Львівського національного університету: етапи розвитку, здобутки та виклики" (Львів, 2020);

14. А. Богуцький, О. Томенюк, А. Яцишин, Р. Дмитрук "Палеогеографія антропогену у львівському університеті: основні здобутки у XXI столітті та перспективи" (Львів, 2020).

\section{Результати досліджень та їхнє обговорення.}

\section{1. Статус сучасної геоморфології.}

Сучасна геоморфологія - наука не лише про рельєф, його генезис, морфологію, вік і динаміку, процеси рельєфоутворення і впливаючі на них чинники та умови, а й про взаємодії рельєфу з компонентами ландшафту, 3 господарськими об'єктами і системами, 3 людиною та іiі розумом, силою i конструктами, про наслідки цих взаємодій (економічні, екологічні, етнокультурні, управлінські тощо), про геоінформаційні і прогностичні моделі рельєфу та процесів, що в ньому відбуваються, про наукові, методичні i 
прикладні засади їхнього вивчення. Рельєф трактують як сукупність різнорангових тривимірних форм, які розвиваються у просторі і часі під впливом природних та антропогенних чинників, і як неперервне поле висот земної поверхні, поверхні планет та інших небесних тіл.

Рельєф, його риси і властивості, процеси рельєфоутворення є об'єктом геоморфології. В різних галузях геоморфології рельєф вивчають 3 різних позицій, під тим чи іншим кутом зору, а здобуті знання використовують для вирішення теоретичних, методологічних, прикладних проблем і завдань.

Окрім геоморфологів, рельєф вивчають геологи, ландшафтознавці, грунтознавці, гідрологи, екологи, землевпорядники, геодезисти, фахівці інших наук з їхніх позицій.

Організаційно фахівців геоморфологічного профілю готують дві кафедри геоморфології (вони у своїй назві містять ще одну складову) - у Києві і Львові. Геоморфологи також працюють на географічних чи геолого-географічних факультетах Одеського, Харківського, Чернівецького, Ужгородського, Волинського, Таврійського національних університетів, Луцького національного технічного університету, Тернопільського національного педагогічного університету імені Володимира Гнатюка, в Інституті географії НАН України, інших установах та організаціях. Випускники кафедр геоморфології мають певні можливості працювати в геологічних експедиціях, інституціях інженерногеологічного і геотехнічного спрямування, землевпорядних та інженернобудівельних фірмах й організаціях, а також закладах вищої освіти, в яких у навчальних планах передбачені дисципліни геоморфологічної тематики або функціонують кафедри, дотичні до географії, геології та геоморфології.

Відсутність у «табелі про ранги» чіткого статусу для фахівця-геоморфолога створює проблеми під час працевлаштування випускників-геоморфологів, що знижує престиж цієї спеціальності.

2. Співвідношення української $і$ зарубіжної геоморфології.

Українська геоморфологія програє своїм зарубіжним сестрам насамперед за:

- рівнем інструментального забезпечення своїх досліджень;

- презентацією отриманих результатів (вони часто недоступні для широкого кола читачів, оскільки їх публікують, здебільшого, українською чи російською мовами в журналах, які не входять до високорейтингових наукометричних баз);

- недостатнім ступенем детальності та інноваційності і практичної затребуваності отриманих висновків;

- недостатнім рівнем ознайомлення українських учених 3 напрямами досліджень та отриманими зарубіжними вченими результатами;

- недостатнім рівнем лабораторного та геоінформаційнопрограмного забезпечення дослідницьких робіт;

- рівнем підтримки геоморфології на рівні держави та ії інституцій.

3. Необхідні кроки геоморфології як соціально затребуваної науки.

На наш погляд, для вирішення цього завдання геоморфологія повинна більше уваги приділяти :

- теоретико-методичним питанням (оцінюванню стійкості рельєфу 
до техногенних впливів i навантажень, пізнанню механізмів функціонування геоморфосистем різних генезису, рангу, господарської та природоохоронної цінності, удосконаленню методики їхнього дослідження, використанню даних ДЗЗ тощо);

- оцінюванню гостроти еколого-геоморфологічних проблем, створюваних різними видами господарської діяльності, ендогенними та екзогенними чинниками тощо (екологічна геоморфологія);

- змінам клімату i їхнім наслідкам для розвитку процесів рельєфоутворення, оцінюванню впливу діяльності людини на уразливі геоморфосистеми (кліматична, динамічна й антропогенна геоморфологія);

- оцінюванню придатності рельєфу для його оптимального використання різними галузями господарства (прикладна, інженерна / конструктивна геоморфологія);

- оцінюванню естетики, туристичної привабливості рельєфу (естетична, туристична геоморфологія);

- отриманню кількісних показників хронології геоморфологічних подій на усіх етапах розвитку рельєфу різного генезису;

- моделюванню і прогнозуванню змін станів рельєфу, розвитку геоморфологічних процесів (геоморфологічна прогностика),

- дистанційним дослідженням рельєфу, геоморфосистем і процесів рельєфоутворення (динамічна геоморфологія, застосування БПЛА і ДЗЗ у вивченні станів геоморфосистем та їхнього функціонування) та ін.

4. Важливі напрями досліджень, які варто розвивати в найближчій перспективі.

Перспективними напрямами геоморфологічних досліджень української геоморфології у XXI столітті вважаємо такі:

1) атласне i тематичне цифрове картографування станів водосховищ i процесів, що відбуваються в їхніх чашах, прибережній смузі та на водозборах;

2) геоморфологічні та геоекологічні дослідження озерно-басейнових систем їхньої будови, поширення та інтенсивності розвитку сучасних процесів, оцінювання еколого-геоморфологічного стану, моніторингу його змін під впливом антропогенних та кліматичних чинників;

3) атласне i тематичне картографування річково-басейнових систем 3 відображенням їх геоморфологічної будови, стану, поширення та інтенсивності розвитку сучасних процесів (руслових і схилових), ризиків для господарства, угідь, комунікацій і населення, гідроекологічних проблем;

4) дослідження геоморфологічних умов виникнення, сучасного стану i тенденцій змін водно-болотних угідь різних регіонів України;

5) вивчення гідроморфологічних проблем річок різних рангів, їхнього відображення на тематичних картах, обгрунтування способів їхнього вирішення та збереження водних ресурсів і поліпшення їхнього стану;

6) постановка урбоекогеоморфологічних досліджень (стану і функціонування міських поселень різних типів і категорій);

7) оцінювання геоморфологічних ризиків функціонування різних галузей та об'єктів природокористування в умовах глобальних і регіональних змін клімату, 
прояву екстремальних паводків, селів, лавин, зсувів, засух і суховіїв;

8) робота над створенням кадастру зсувів, ярів, карстових форм рельєфу, сельових потоків, лавинних вогнищ, водоспадів, останцевих форм тощо;

9) дослідження інженерно-геоморфологічних проблем, оцінювання придатності рельєфу для його використання в різних галузях господарства;

10) удосконалення методичних засад антропогенної геоморфології, класифікацій антропогенного рельєфу і процесів, прогнозування їхнього розвитку;

11) оцінювання впливів гірничо-видобувної діяльності на стан земної поверхні, іiі деформації, розвиток процесів підтоплення, заболочення, вивчення впливу на річки, озера на прилеглій території, інших наслідків;

12) розвиток белігеративної геоморфології (оцінка захисних функцій рельєфу, наслідків військової діяльності, обгрунтування рекультиваційних заходів тощо);

13) геоморфологічне забезпечення туризму (обгрунтування прокладання водних, гірських, височинних і низовинних туристських маршрутів, створення геоморфолого-туристичного супроводу туристично-рекреаційної діяльності тощо);

14) оцінка рельєфу як ресурсу природокористування (для оптимального розміщення об'єктів водогосподарського, сільськогосподарського, лісогосподарського, транспортного, промислового, житлового, туристичного, природоохоронного та іншого призначення);

15) розвиток пошукової геоморфології (удосконалення пошуків родовищ корисних копалин, будівельних матеріалів, питної води тощо);

16) розвиток естетичної, сенситивної (почуттєвої, враженнєвої) геоморфології;

17) оцінювання геоекологічної безпеки/небезпеки функціонування різнорангових геопросторових об'єктів - природних, створених чи модифікованих господарською діяльністю людини тощо;

18) обгрунтування формування геоморфологічної складової екомережі та системи природно-заповідних територій, геопарків, аквапарків тощо;

19) оцінювання рельєфу як середовища життя і діяльності людини, його впливу на здоров'я та умови життєдіяльності населення;

20) оцінювання різних форм рельєфу як концентраторів / розсіювачів забруднювальних речовин (тобто як геоекологічного чинника);

21) дослідження різноманітних полів (геофізичних, геохімічних, гідрохімічних тощо) та аномалій і їхнього впливу на людину, iї життя і здоров'я;

22) експериментальні дослідження, моделювання (лабораторне, математичне, геоінформаційне) i прогнозування розвитку геоморфологічних процесів та динамічних форм рельєфу тощо.

Питання стану, здобутків і проблем палеогеоморфологічних досліджень варто розглянути в окремій публікації.

4. Для успішного вирішення циих завдань геоморфологія покликана :

- дбати про свою репутацію, ширше впроваджувати результати досліджень у господарську практику, оптимізацію стану навколишнього середовища, управління природокористуванням та охороною природи; 
- домагатися фінансування геоморфологічних досліджень з різних джерел;

- суттєво оновлювати матеріально-технічне забезпечення, інструментальну і геоінформаційну базу геоморфологічних досліджень;

- ширше запроваджувати у геоморфологічні дослідження та у практично орієнтовані вишукування методи геоінформаційнокартографічного моделювання та дистанційного зондування, лабораторних аналізів, прогностичний апарат;

- готувати високопрофесійних фахівців-геоморфологів, забезпечувати їх достойною оплатою праці.

5. Перспективи украӥнської геоморфології.

Стосовно перспектив розвитку геоморфологічної науки в Україні відповісти доволі складно. Якщо у світі геоморфологія є затребуваною наукою, то, очевидно, вона має шанс вижити і на сучасному етапі розвитку суспільства. Отож сподіваємося, що і в Україні вона матиме такий шанс, адже в її структурі добре розвиненою $є$ не лише теоретична складова, а й прикладна. Щораз частіше геоморфологія допомагає вирішувати інженерно-технічні і природоохоронні завдання, захищати узбережжя морів, озер, водосховищ, заплавно-руслові комплекси, угіддя i поселення від руйнівного впливу несприятливих екзодинамічних процесів, проектувати і будувати дороги, господарські споруди, туристично-рекреаційні та інші об'єкти 3 високим ступенем стабільності і надійності їхного функціонування, знаходити родовища природних ресурсів, вирішувати геоекологічні проблеми.

Сподіваємося, що демократизація суспільного життя, європейські устремління держави ширше відчинять двері ринків праці країн ЄС для добре підготовлених українських фахівців-геоморфологів. Цей чинник теж має слугувати прискорювачем прогресу української геоморфологічної науки i практики.

\section{Висновки :}

1. Українська геоморфологія за свою майже 140-річну історію формування і розвитку перетворилася у достатньо диференційовану, багатогалузеву науку, 3 міцною теоретичною базою (морфоструктурно-морфоскульптурною, палеогеоморфологічною, морфокліматичною, морфодинамічною та геоекологічною складовими), розвинутими інженерно-геоморфологічним, розшуковим, динамічно-геоморфологічним, еколого-геоморфологічним, рекреаційно-туристичним, природоохоронним та іншими напрямами.

2. До дійових осіб, які зробили значний внесок у становлення і розвиток української геоморфології, зачислюємо А. Ремана, Е. Ромера, Г. Тейсейра, С. Рудницького, П. Тутковського, Ю. Полянського, А. Яна, Б. Лічкова, Д. Соболєва, В. Крокоса, В. Бондарчука, П. Заморія, П. Цися, К. Геренчука, О. Маринича, М. Веклича, I. Гофштейна, С. Проходського, М. Волкова, I. Соколовського, I. Черваньова, В. Палієнко, О. Адаменка, А. Богуцького, Ж. Матвї̈шину, Н. Герасименко, А. Оліферова, В. Дублянського, Я. Кравчука, I. Ковальчука, В. Стецюка, Г. Рудька, С. Бортника, О. Ободовського, О. Комлєва, Л. Дубіс, Б. Вахрушева, А. Клюкіна, С.Кострікова, А. Михновича, О. Пилипович, Т. Павловську, В. Шушняка та багатьох інших учених.

3. Перспективними у XXI столітті будуть дослідження, спрямовані на 
розв'язання 22-х завдань, окреслених нами у статті. Вони включають як теоретичні, так і практичні складові, орієнтовані на удосконалення теоретикометодологічних засад геоморфології, впровадження нових методів вивчення і моделювання рельєфу, процесів рельєфоутворення, провокованих ними ризиків для населення, господарства, екологічної стабільності геоморфосистем, геоінформаційно-картографічну візуалізацію результатів досліджень, обгрунтування комплексу процесорегулювальних, екостабілізаційних та природоохоронних заходів, розвиток геоморфологічної освіти, підвищення соціального статусу науки про рельєф і процеси рельєфоутворення.

\section{СПИСОК ВИКОРИСТАНОЇ ЛІТЕРАТУРИ}

Адаменко О. М. Украинская геоморфологическая школа: истоки, становление, взгляд в будущее / O. М. Адаменко, И. П. Ковальчук, Я. С. Кравчук, А. М. Маринич, В. П. Палиенко, Э. Т. Палиенко, И. Г. Черванев // Геоморфология на рубеже XXI века : IV Щукинские чтения. Труды (коллектив авторов). - Москва : Географический факультет МГУ, 2000. C. $37-40$.

Академік Степан Рудницький - основоположник української географічної науки : збірник наукових праць / відп. ред. О. І. Шаблій. - Львів : Львів. держ. ун-т ім. І. Франка, 1994. - 136 с.

Андрій Богуцький : Бібліогр. покажч. / Уклад.: А. Яцишин, Н. Прицюк. - Львів : ВЦ ЛНУ ім. І. Франка, 2008. - 84 с.; іл.

Богуцький А. Палеогеографія антропогену у львівському університеті: основні здобутки у XXI столітті та перспективи / А. Богуцький, О. Томенюк, А. Яцишин, Р. Дмитрук // Проблеми геоморфології i палеогеографії Українських Карпат і прилеглих територій. - Львів : ВЦ ЛНУ ім. І. Франка, 2020. - Вип. 1(11). - С. 30-70.

Бортник С. Кафедра землезнавства та геоморфології Київського університету: погляд з XXI століття / С. Бортник, В. Стецюк, О. Комлєв, Н. Герасименко, T. Лаврук, О. Ковтонюк, Н. Погорільчук, О. Підкова // Проблеми геоморфології і палеогеографії Українських Карпат і прилеглих територій. Львів: ВЦ ЛНУ ім. І. Франка, 2020. - Вип. 1(11). - С.71-84.

Бортник С. Ю. Геоморфологія та палеогеографія у Київському університеті / С. Ю. Бортник, Е. Т. Палієнко, В. В. Стецюк, Н. П. Герасименко, О. О. Комлєв // Фізична географія та геоморфологія. - Київ : ВГЛ Обрії, 2009. - Вип. 56. C. 7-18.

Геренчук К.И. Тектонические закономерности в орографии речной сети Русской равнины / К.И.Геренчук. - Львов: Изд-во Львов. ун-та, 1960. - 240 с.

Гофштейн I. Д. Неотектоніка і морфогенез Верхнього Придністров'я / I. Д. Гофштейн. - Київ : Вид-во АН УРСР, 1962. - 132 с.

Гофштейн И. Д. Неотектоника Карпат / И. Д. Гофштейн. - Киев : Изд-во АН УССР, 1964. - $182 \mathrm{c}$.

Гофштейн И. Д. Неотектоника Западной Волыно-Подолии / И. Д. Гофштейн. Киев : Наук. думка, 1979. - 156 с.

Гофштейн И. Д. Геоморфологический очерк Украинских Карпат / И. Д. Гошфтейн. - Киев : Наук. думка, 1995. - 87 с.

Дмитрієв М. І. Рельєф УСРР (геоморфологічний нарис) / М. І. Дмітрієв. - Харків 
: Радянська школа, 1936. - 168 с.

Жанна Миколаївна Матвіїшина / Уклад. В. І. Передерій, А. С. Івченко, С. П. Дорошкевич, С. П. Кармазиненко та ін.; Відп. ред. Л. Г. Руденко; Інститут географії НАН України. - Київ : Академперіодика, 2018. - 84 с.; 55 іл.

Іван Ковальчук: Біобібліогр. покажч. / Укладачі : Г. Домбровська, А. Михнович; наук. ред. проф. А. Мельник; авт. передм. : проф. Я. Кравчук, доц. М. Симоновська, проф. О. Шаблій; Редкол. : Б. Якимович (голова), І. Грабинський, Г. Домбровська, Я. Кравчук, Я. Хомин. - Львів : ВЦ ЛНУ ім. I. Франка, 2002. - 238 с.: 24 іл., портр. (Українська біобібліографія. Нова серія. Ч. 8; Біобібліографія вчених університету).

Ковальчук I. П. Українська геоморфологія: історія, напрями, завдання, проблеми / І. П. Ковальчук // Тези доп. VII з’їзду УГТ. - Київ, 1995. - С. 14-16.

Ковальчук І. П. Українська екогеоморфологія: стан, завдання, перспективи, проблеми / І. П. Ковальчук // Українська геоморфологія: стан і перспективи: матеріали Міжнар. наук.-практ. конф. - Львів : Меркатор, 1997. - С. 37-41.

Ковальчук І. Кафедрі геоморфології і палеогеографії Львівського національного університету - 50 / I. Ковальчук, Я. Кравчук // Вісник Львів. ун-ту. Серія геогр. - Львів : ВЦ ЛНУ ім. І. Франка, 2001. - Вип. 28. - С. 3-15

Ковальчук I. Вектори розвитку української геоморфології / І. Ковальчук // Геоморфологічні дослідження в Україні: минуле, сучасне, майбутнє : матеріали міжнародної конференції. - Львів : ВЦ ЛНУ ім. І. Франка, 2001. C. $192-200$.

Ковальчук I. Професор Петро Цись: внесок у розвиток української геоморфології / І. Ковальчук // Історія української географії. - Тернопіль, 2004. - Вип.10. - С. $7-12$.

Ковальчук. І. Професор Петро Цись / І. Ковальчук - упорядник. - Львів : ВЦ ЛНУ ім. І. Франка, 2004 а. - 433 с.

Ковальчук І. П. Українська геоморфологія на межі тисячоліть: здобутки, проблеми, перспективи / I. П. Ковальчук // Фізична географія та геоморфологія. - Київ : ВГЛ Обрії, 2005. - Вип. 49. - С. 10-17.

Ковальчук И. П. Проблемы и перспективы геоморфологических исследований территории Украины / И. П. Ковальчук // Отечественная геоморфология: прошлое, настоящее, будущее: материалы XXX Пленума Геоморфологической комиссии РАН. - Санкт-Петербург. - 2008. С. 364-366.

Ковальчук І. П. Українська екологічна геоморфологія: історія, сьогодення, майбутне / І. П. Ковальчук // Фізична географія та геоморфологія. - Київ: ВГЛ Обрії, 2009. - Вип. 56. - С. 55-63.

Ковальчук I. Екологічна геоморфологія в Україні: історія, сьогодення, перспективи / I. Ковальчук // Стан і перспективи розвитку конструктивної географії: матеріали Всеукраїнської науково-практичної конференції, присвяченої десятиріччю заснування кафедри конструктивної географії i картографії (Львів-Ворохта, 6-8 травня 2010 рік). - Львів: ВЦ ЛНУ ім. I. Франка, 2010. - С. 31-43.

Ковальчук І. П. Українські геоморфологічні наукові школи: джерела, здобутки, перспективи / І. П. Ковальчук // Фізична географія і геоморфологія. - Київ : ВГЛ Обрії, 2012. - Вип. 2 (66). - С. 144-152. 
Ковальчук И.П. Антропогенная геоморфология как наука и учебная дисциплина / И. П. Ковальчук, О.В.Колтун // Антропогенная геоморфология: наука и практика: материалы XXXII Пленума Геоморфологической комиссии РАН (г. Белгород, 25-29 сентября 2012 г.). - Москва : Белгород, 2012. - С. 43-49.

Ковальчук I. Розвиток географічної науки у Львові за роки незалежності України: структура, наукові школи, здобутки, проблеми / I. Ковальчук // Вісник Львівського університету. Серія географічна. - 2013. - Вип. 46. C. $172-185$.

Кравчук Я. Кафедра геоморфології і палеогеографії Львівського національного університету імені Івана Франка (1950-2004рр.) / Я. Кравчук // Проблеми геоморфології і палеогеографії Українських Карпат і прилеглих територій : матеріали Міжнародного семінару, присвяченого 90-річчю від дня народження засновника кафедри геоморфології і палеогеографії професора Петра Цися (30 вересня - 3 жовтня 2004 року). - Львів : ВЦ ЛНУ ім. I. Франка, 2004. - C. 3-23.

Кравчук Я. С. Кафедра геоморфології і палеогеографії: довідкове видання / За заг. ред. проф. Кравчука Я. С. - Львів : ВЦ ЛНУ ім. І. Франка, 2007. - 56 с.

Кравчук Я. Геоморфологія і палеогеографія у Львівському національному університеті (1961-2011) / Я. Кравчук // Вісник ЛНУ ім. І. Франка. Серія географічна. - Вип. 40. - Ч. 1. - 2012. - С. 32-45.

Кравчук Я. Академік Степан Рудницький - перший український геоморфолог /Я. Кравчук // Історія української географії. - Вип. 36. - 2017. - С. 22-32.

Кравчук Я. Вивчення Степаном Рудницьким морфології, генезису та історії розвитку рельєфу Поділля /Я. Кравчук, Ю. Зінько // Проблеми геоморфології і палеогеографії Українських Карпат і прилеглих територій : збірник наукових праць. - 2019. - Вип. 1 (9). - С. 3-20.

Кравчук Я. Кафедра геоморфології і палеогеографії Львівського національного університету: етапи розвитку, здобутки та виклики / Я. Кравчук, I. Ковальчук, Л. Дубіс // Проблеми геоморфології і палеогеографії Українських Карпат і прилеглих територій : Збірник наукових праць, присвячений 70-річчю заснування кафедри геоморфології і палеогеографії. - Львів, 2020. - Вип. 1(11). - C. 3-29.

Крокос В. І. Матеріали до характеристики четвертинних покладів східної і південної України / В. І. Крокос // Матеріали дослідження грунтів України. Секція грунтознавства. - Харків, 1927. - Т. 9. - Вип. 5. - С. 1-325.

Наукова школа інженерної та екологічної геоморфології у Київському національному університеті імені Тараса Шевченка : довідкове видання / Е. Т. Палієнко, Г. І. Рудько, Ю. А. Сілецький, В. В. Стецюк, Т. І. Ткаченко; за ред. В. В. Стецюка. - Київ: Слово, 2010. - 80 с.

Науковий доробок доктора геолого-мінералогічних наук, доктора географічних наук, доктора технічних наук, професора Рудька Георгія Ілліча 1980-2019 pp. (І півріччя) [Текст] : бібліогр. покажч. / [упоряд. Ю.В.Бабич]. - Київ; Чернівці : Букрек, 2019. - 107 с.

Полянський Ю. Подільські етюди: тераси, леси і морфольогія галицького Поділля над Дністром / Ю. Полянський // Зб. матем.-природ.-лікар. секції НТШ. - 1929. -Т. 20. - 191 с.

Рудницький С. Знадоби до морфології карпатського сточища Дністра / Зб. 
матем.- природопис.-лікар. секції НТШ, Львів : НТШ. - 1905. - Т. Х. - 85 с.

Рудницький С. Знадоби до морфології підкарпатського сточища Дністра / С. Рудницький // Зб. матем.-природопис.-лікар. секції НТШ. - 1907. -T.XI. $79 \mathrm{c}$.

Рудницький С. Знадоби до морфології подільського сточища Дністра / С. Рудницький // Зб. матем.-природопис.-лікар. секції НTШ. - 1913. - T.XVI. $310 \mathrm{c}$.

Соколовський I. Л. Закономірності розвитку рельєфу України / І. Л. Соколовський. - АН УРСР. Сектор географії. - Київ : Наукова думка, 1973. - $215 \mathrm{c}$.

Тутковский П. А. Конечные морены, валунные полосы и озы в Южном Полесье / П. А. Тутковский // Зап. Киев. об-ва естествоиспытателей. - 1902. - Т.16. Вып. 2. - С. 1-108

Цись П. М. Про основні генетичні типи рельєфу західних областей України / П М. Цись // Географ. зб. Укр. ГТ. - Київ: Вид-во АН УРСР, 1961. - Вип. 4. C. 25-34.

Черваньов І. Г. Флювіальні геоморфосистеми / І. Г. Черваньов, С. В. Костріков, Б. Н. Воробйов - Харків : ХНУ ім. В .Н. Каразіна, 2006. - 322 с.

Черваньов І.Г. Дослідження рельєфу представниками харківської геоморфологічної школи / I. Г. Черваньов. - Український географічний журнал. - № 4. - С. 3-7.

Romer E. Proba morfometrycznej analizy grzbietów Karpat Wschodnich / E. Romer. Lwów, 1909. - Roczn. 34. - S. 7-9.

Świderski B. Geomorfologia Czarnohory / B. Świderski. - Warszawa: Wyd. Kasy im. Mianowskiego, 1937. - 96 ss.

Teisseyre H. Czwartorzęd na predgórzu arkuszu Sambor i Dobromil / H. Teisseyre // Rocz. Pol. Tow. Geol. - 1938. - T. 13. - S. 31-81.

Zierhoffer A. Pólnocna krawędź Podola w świetle mapy powierzchni kredowej / A. Zierhoffer // Księga pam. XII Zjazdu Lek. Przyr. - Warszawa, 1926. - S. 116117.

\section{REFERENCES}

Adamenko, O. M., Kovalchuk, Y. P., Kravchuk, Ya. S., Marynych, A. M., Palyenko, V. P., Palyenko, Э. T., Chervanev, Y. H. (2000) Ukraynskaia heomorfolohycheskaia shkola: ystoky, stanovlenye, vzghliad $\mathrm{v}$ budushchee [Ukrainian geomorphological school: origins, formation, look into the future]. In Heomorfolohyia na rubezhe XXI veka : IV Shchukynskye chtenyia. Trudy. Moskva : Heohrafycheskyi fakultet MHU, 37-40. (In Russian)

Shablii, O. (Eds.). (1994) Akademik Stepan Rudnytskyi - osnovopolozhnyk ukrainskoi heohrafichnoi nauky : zbirnyk naukovykh prats. [Academician Stepan Rudnytsky the founder of Ukrainian geographical science: a collection of scientific works]. Lviv : Lviv. derzh. un-t im. I. Franka. (In Ukrainian).

Yatsyshyn, A., Tomeniuk, O. (Eds.). (2008) Andrii Bohutskyi : Bibliohr. Pokazhch. [Andriy Bogutsky: Bibliographic index]. Lviv : VC LNU im. I. Franka. (In Ukrainian).

Bohutskyi, A., Tomeniuk, O., Yatsyshyn, A., Dmytruk, R. (2020). Paleoheohrafiia antropohenu u Lvivskomu universyteti: osnovni zdobutky u XXI stolitti ta perspektyvy. [Quaternary palaeogeography at the Lviv University: main 
achievements in the XXI century and prospects]. In Problemy heomorfolohii $i$ paleoheohrafii Ukrainskykh Karpat i prylehlykh terytorii. Lviv : VC LNU im. I. Franka, 1 (11), 42-71. (In Ukrainian).

Bortnyk, S., Stetsiuk, V., Komliev, O., Herasymenko N., Lavruk, T., Kovtoniuk, O., Pohorilchuk, N., Pidkova, O. (2020) Kafedra zemleznavstva ta heomorfolohii Kyivskoho universytetu: pohliad z XXI stolittia. [Department of Physical Geography and Geomorphology, University of Kiev: a view from the XXI century]. In Problemy heomorfolohii $i$ paleoheohrafii Ukrainskykh Karpat i prylehlykh terytorii. Lviv : VC LNU im. I. Franka, 1(11), 71-84. (In Ukrainian)

Bortnyk, S. Iu., Paliienko, E. T., Stetsiuk, V. V., Herasymenko, N. P., Komliev, O. O. (2009). Heomorfolohiia ta paleoheohrafiia u Kyivskomu universyteti. [Geomorphology and paleogeography at the University of Kiev]. In Fizychna heohrafiia $i$ heomorfolohiia. Kyiv : Obrii, 56, 7-18. (In Ukrainian)

Herenchuk, K.Y. (1960) Tektonycheskye zakonomernosty $v$ orohrafyy rechnoi sety Russkoi ravnyny. [Tectonic regularities in the orography of the river network of the Russian Plain]. Lvov. (In Russian)

Hofshtein I. D. (1962). Neotektonika i morfohenez Verkhnoho Prydnistrov'ia. [Neotectonics and morphogenesis of Upper Dnister Region]. Kyiv. (In Ukrainian).

Hofshtein, I. D. (1964). Neotektonika Karpat. [Neotectonics of the Carpathians]. Kyiv. (In Russian).

Hofshtein, I. D. (1979). Neotektonika Zapadnoj Volyno-Podolii. [Neotectonics of Western Volhyn-Podillia]. Kyiv. (In Russian).

Hofshtein, I. D. (1995). Geomorfologicheskij ocherk Ukrainskih Karpat. [Geomorphological sketch of the Ukrainian Carpathians]. Kyiv : Naukova dumka. (In Russian)

Dmytriev M. I. (1936). Relief USSR (geomorfologicznyj narys). [Relief of the USSR (geomorphological sketch)]. Kharkiv : Radianska schkola (In Ukrainian).

Perederii, V.I., Ivchenko, A.S., Doroshkevych, S.P., Karmazynenko, S.P. et all (2018) (Eds.) Zhanna Mykolaivna Matviishyna. [Zhanna Mykolayivna Matviishyna]. Kyiv : Akademperiodyka. (In Ukrainian)

Melnyk, A. (Eds.) (2002) Ivan Kovalchuk: Biobibliohr. pokazhch. [Ivan Kovalchuk: Biobibliographic index]. Lviv. (In Ukrainian)

Kovalchuk, I.P. (1995) Ukrainska heomorfolohiia: istoriia, napriamy, zavdannia, problemy. [Ukrainian geomorphology: history, directions, tasks, problems]. In Tezy dop. VII zizdu UHT. Kyiv, 14-16. (In Ukrainian)

Kovalchuk, I. P. (1997) Ukrainska ekoheomorfolohiia: stan, zavdannia, perspektyvy, problemy. [Ukrainian ecogeomorphology: state, tasks, prospects, problems]. In Ukrainska heomorfolohiia: stan i perspektyvy. Lviv : Merkator, 37-41. (In Ukrainian)

Kovalchuk, I., Kravchuk, Ya. (2001). Kafedri heomorfolohii i paleoheohrafii Lvivskoho natsionalnoho universytetu - 50. [The 50th anniversary of the Geomorphology and Paleogeography Deapartment of Lviv National University]. In Visnyk Lviv. un-tu. Seriia heohr. Lviv : VC LNU im. I. Franka, 28, 3-15. (In Ukrainian).

Kovalchuk, I. (2001) Vektory rozvytku ukrainskoi heomorfolohii. [Vectors of development of Ukrainian geomorphology]. In Heomorfolohichni doslidzhennia $v$ Ukraini: mynule, suchasne, maibutnie. Lviv : VC LNU im. I. Franka, 192-200. (In 
Ukrainian)

Kovalchuk, I. (2004). Profesor Petro Tsys: vnesok u rozvytok ukrainskoi heomorfolohii. [Professor Petro Tsys: A contribution to the development of Ukrainian geomorphology]. In Istoriia ukrainskoi heohrafii, Ternopil, 10, 7-12. (In Ukrainian).

Kovalchuk, I. (Eds.). (2004 a). Profesor Petro Tsys. [Profesor Petro Tsys]. Lviv : VC LNU im. I. Franka. (In Ukrainian).

Kovalchuk, I. P. (2005) Ukrainska heomorfolohiia na mezhi tysiacholit: zdobutky, problemy, perspektyvy. [Ukrainian geomorphology at the turn of the millennium: achievements, problems, prospects]. In Fizychna heohrafiia ta heomorfolohiia, 49, 10-17. (In Ukrainian)

Kovalchuk I. P. (2008) Problemy i perspektyvy heomorfolohycheskykh issledovanyy terrytoryy Ukrayny [Problems and prospects of geomorphological studies of the territory of Ukraine]. In Otechestvennaia heomorfolohyia: proshloe, nastoiashchee, budushchee: materyaly XXX Plenuma Heomorfolohycheskoi komyssyy RAN. SanktPeterburh, 364-366. (In Russian)

Kovalchuk, I. P. (2009) Ukrainska ekolohichna heomorfolohiia: istoriia, sohodennia, maibutnie. [Ukrainian ecological geomorphology: history, present, future]. In Fizychna heohrafiia ta heomorfolohiia, 56, 55-63. (In Ukrainian)

Kovalchuk I. (2010) Ekolohichna heomorfolohiia v Ukraini: istoriia, sohodennia, perspektyvy. [Ecological geomorphology in Ukraine: history, present, prospects]. In Stan i perspektyvy rozvytku konstruktyvnoi heohrafii. Lviv, 31-43. (In Ukrainian)

Kovalchuk I. P. (2012) Ukrainski heomorfolohichni naukovi shkoly: dzherela, zdobutky, perspektyvy [Ukrainian geomorphological scientific schools: sources, achievements, prospects]. In Fizychna heohrafiia ta heomorfolohiia, 2 (66), 144152. (In Ukrainian)

Kovalchuk, I. P., Koltun, O. V. (2012) Antropohennaia heomorfolohyia kak nauka y uchebnaia dystsyplyna [Anthropogenic geomorphology as a science and academic discipline]. In Antropohennaia heomorfolohyia: nauka y praktyka. Moskva : Belhorod, 43-49. (In Russian)

Kovalchuk, I. (2013) Rozvytok heohrafichnoi nauky u Lvovi za roky nezalezhnosti Ukrainy: struktura, naukovi shkoly, zdobutky, problemy. [Development of geographical science in Lviv during the years of independence of Ukraine: structure, scientific schools, achievements, problems]. In Visnyk Lviv. un-tu. Seriia heohr. Lviv : VC LNU im. I. Franka, 46, 172-185. (In Ukrainian)

Kravchuk, Ya. (2004). Kafedra heomorfolohii i paleoheohrafii Lvivskoho natsionalnoho universytetu imeni Ivana Franka (1950-2004 rr.). [Department of Geomorphology and Paleogeography, Ivan Franko National University of Lviv (1950-2004)]. In Problemy heomorfolohii i paleoheohrafii Ukrainskykh Karpat $i$ prylehlykh terytorii : materialy Mizhnarodnoho seminaru, prysviachenoho 90richchiu vid dnia narodzhennia zasnovnyka kafedry heomorfolohii i paleoheohrafii profesora Petra Tsysia (30 veresnia - 3 zhovtnia 2004 roku). Lviv : VC LNU im. I. Franka, 3-23. (In Ukrainian)

Kravchuk, Ya. (Eds.). (2007). Kafedra heomorfolohii i paleoheohrafii : dovidkove vydannia. [Department of Geomorphology and Paleogeography: reference edition]. Lviv : VC LNU im. I. Franka. (In Ukrainian)

Kravchuk, Ya. (2012). Heomorfolohiia i paleoheohrafiia u Lvivskomu universyteti 
(1961-2011). [Geomorphology and paleogeography at Lviv University (19612011)]. In Visnyk Lviv. un-tu. Seriia heohr. Lviv : VC LNU im. I. Franka, 40, 1, 3245. (In Ukrainian)

Kravchuk Ya. (2017). Akademik Stepan Rudnytskyi - pershyi ukrainskyi heomorfoloh. [Academician Stepan Rudnytsky is the first Ukrainian geomorphologist]. In Istoriia Ukrainskoi heohrafii, 36, 22-32. (In Ukrainian)

Kravchuk, Ya., Zinko, Yu. (2019). Vyvchennia Stepanom Rudnytskym morfolohii, henezysu ta istorii rozvytku reliefu Podillia. [Studies of the morphology, genesis and the history of development of Podillia relief by Stepan Rydnytskyi]. In Problemy heomorfolohii i paleoheohrafii Ukrainskykh Karpat i prylehlykh terytorii, 1 (9), 3-20. (In Ukrainian).

Kravchuk, Ya., Kovalchuk, I., Dubis, L. (2020) Kafedra heomorfolohii i paleoheohrafii Lvivskoho natsionalnoho universytetu: etapy rozvytku, zdobutky ta vyklyky. [Department of Geomorphology and Paneogeography of the Ivan Franko National University of Lviv: Stages of Development, Achievements and Challenges]. In In Problemy heomorfolohii i paleoheohrafii Ukrainskykh Karpat i prylehlykh terytorii, 1(11), 3-29. (In Ukrainian)

Krokos, V. I. (1927). Materialy do kharakterystyky chetvertynnykh pokladiv skhidnoi i pivdennoi Ukrainy. [Materials for the characteristics of Quaternary deposits of Eastern and Southern Ukraine]. In Materials of research of soils of Ukraine. Section of Soil Science, 9(5), 1-325. Kharkiv. (In Ukrainian).

Paliienko, E.T., Rudko, I.H., Siletskyi, Yu.A., Stetsiuk, V.V., Tkachenko, T.I. (2010) Naukova shkola inzhenernoi ta ekolohichnoi heomorfolohii u Kyivskomu natsionalnomu universyteti imeni Tarasa Shevchenka : dovidkove vydannia. [Scientific School of Engineering and Ecological Geomorphology at Taras Shevchenko National University of Kyiv: reference edition]. Kyiv : Slovo. (In Ukrainian)

Babych, Yu.V. (Eds.). (2019) Naukovyi dorobok doktora heoloho-mineralohichnykh nauk, doktora heohrafichnykh nauk, doktora tekhnichnykh nauk, profesora Rudka Heorhiia Illicha 1980-2019 rr. (I pivrichchia) [Scientific achievements of Doctor of Geological and Mineralogical Sciences, Doctor of Geographical Sciences, Doctor of Technical Sciences, Professor Rudko Georgy Ilyich 1980-2019.]. Kyiv, Chernivtsi : Bukrek. (In Ukrainian)

Polanski, Yu. (1929). Podilski etiudy: terasy, lesy i morfolohiia Halytskoho Podillia nad Dnistrom. [Podolien studies: terraces, loesses and morphology of the Galician Podillya on the Dnister]. In Zbirnyk matematychno-pryrodopysno-likarskoi sektsii NTSh, 20, 1-191. (In Ukrainian).

Rudnytskyi S. (1905). Znadoby do morfolohii karpatskoho stochyshcha Dnistra. [Knowledge of the morphology of the carpathian Dniester basin]. In Zbirnyk matematychno-pryrodopysno-likarskoi sektsii NTSh, 10, 1-85. (In Ukrainian).

Rudnytskyi S. (1907). Znadoby do morfolohii pidkarpatskoho stochyshcha Dnistra. [Knowledge of the morphology of the Subcarpathian Dniester basin]. In Zbirnyk matematychno-pryrodopysno-likarskoi sektsii NTSh, 11, 1-80. (In Ukrainian).

Rudnytskyi S. (1913). Znadoby do morfolohii podilskoho stochyshcha Dnistra. [Knowledge of the morphology of the Podolian Dniester basin]. In Zbirnyk matematychno-pryrodopysno-likarskoi sektsii NTSh, 16, 1-311. (In Ukrainian).

Sokolovskyi, I. L. (1973) Zakonomirnosti rozvytku reliefu Ukrainy. [Regularities of 
relief development of Ukraine]. In AN URSR. Sektor heohrafii. Kyiv : Naukova dumka. (In Ukrainian)

Tutkovsky, P. A. (1902). Konechnye moreny, valunnye polosy i ozy v Juzhnom Poles'e [Terminal moraines, boulder strips and ozes in South Polesie]. In Notes of the Kyiv Society of Naturalists, 16(2), 1-108. (In Russian).

Tsys, P. M. (1961) Pro osnovni henetychni typy reliefu zakhidnykh oblastei Ukrainy. [About the main genetic types of relief of the western regions of Ukraine]. In Heohraf. zb. Ukr. HT. Kyiv: Vyd-vo AN URSR, 4, 25-34. (In Ukrainian)

Chervanov, I. H., Kostrikov, S.V., Vorobiov, B.N. (2006) Fliuvialni heomorfosystemy. [Fluvial geomorphosystems]. Kharkiv : KhNU im. V .N. Karazina. (In Ukrainian)

Chervanov I. H. (2012) Doslidzhennia reliefu predstavnykamy kharkivskoi heomorfolohichnoi shkoly. [Relief research by representatives of the Kharkiv geomorphological school]. In Ukrainskyi heohrafichnyi zhurnal, 4, 3-7. (In Ukrainian)

Romer E. (1909) Proba morfometrycznej analizy grzbietów Karpat Wschodnich. [An attempt at the morphometric analysis of the Eastern Carpathian ridge]. In Roczn. Lwów, 34, 7-9. (in Polish)

Świderski B. (1937) Geomorfologia Czarnohory. [Chornohora geomorphology]. Warszawa : Wyd. Kasy im. Mianowskiego. (in Polish)

Teisseyre, H. (1938). Czwartorzęd na predgórzu arkuszu Sambor i Dobromil [Quaternary in the foreground of the Sambor and Dobromil sheets]. In Rocz. Pol. Tow. Geol., 13, 31-81. (in Polish)

Zierhoffer A. (1926) Pólnocna krawędź Podola w świetle mapy powierzchni kredowej [The northern suburbs of Podillia on the map of the chalky surface] / In Ksiegga pam. XII Zjazdu Lek. Przyr. Warszawa, 116-117 (in Polish).

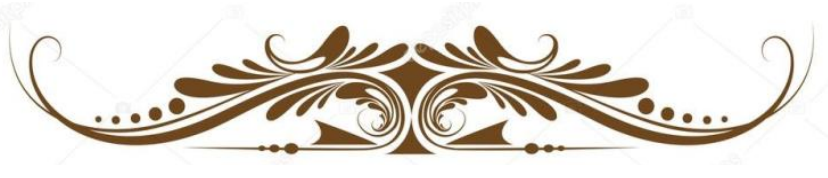

